\title{
Effect of Cropping System and Rice Residue Retention on Crop Productivity and Soil Physical Properties in Rice Based Cropping System of Bangladesh
}

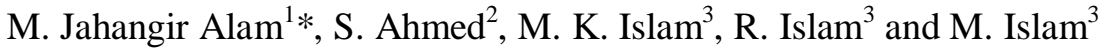 \\ ${ }^{I}$ OFRD, Bangladesh Agricultural Research Institute, Gaibandha, Bangladesh $;{ }^{2}$ International Rice \\ Research Institute, Bangladesh; ${ }^{3}$ RARS, Bangladesh Agricultural Research Institute, Jashore, \\ Bangladesh
}

*Corresponding author and Email: jahangir.bari@ gmail.com

Received: 24 January 2019

Accepted: 09 November 2019

\begin{abstract}
Cropping systems of Bangladesh are highly diverse and cultivation costs of puddled transplanted rice (PTR) are high. Therefore, an improved system is needed to address the issues, a field experiment was conducted during 2011-2013 to evaluate system intensification with varying degrees of cropping systems and residue retention. Four cropping systems (CSE) namely CSE1: T. boro rice-T. aman rice (control), CSE2: wheat-mungbean-T. aman rice (wheat and mungbean sown using a power tilleroperated seeder (PTOS) with full tillage in a single pass; puddled transplanted aman), CSE3: wheatmungbean-dry seeded DS aman rice (DSR), and CSE4: wheat-mungbean-DS aman rice (all sown by PTOS with strip tillage) were compared. Two levels of aman rice residue retention (removed; partial retention i.e. $40 \mathrm{~cm}$ of standing stubble) were compared in sub plots. Grain yield was significantly higher (by 11\%) when wheat was grown after DSR than PTR. Similarly, PTR and DSR (aman rice) produced statistically similar crop yields. Rice residue retention resulted a significantly higher (by $10 \%$ ) wheat yield and a slightly increased (by 6\%) mungbean yield than that of residues removed. The system productivity of CSE4 was significantly higher (by 10\%) than CSE1 when averaged of the two years data. Partial aman residue retention gave significantly higher system yield than residue removal (by $0.6 \mathrm{t} \mathrm{ha}^{-1}$ ). After two years, no effect of CSE or partial aman residue retention was found on soil physical property (bulk density) of the top soil. Therefore, CSE4 along with residue retention would be more effective for sustainable crop production.
\end{abstract}

Keywords: Cropping system, rice residue retention, crop intensification, system productivity, soil physical properties

\section{Introduction}

Rice is the staple food in Bangladesh that contributes $95 \%$ of the total food grain consumption (BBS, 2011), about two-thirds of the total calorie supply and half of the total protein intake per person (Begum and Luc D'Haese, 2010). Wheat is the second most important cereal crop that contributes $7 \%$ of the total output of food cereals (Hossain and Teixeira, 2013), with low average yield of rice and wheat compared to other countries (Bhowmik et al., 2012). Although rice production has increased more than three folds in the last few decades, the country still could not attain sustainable self-sufficiency in food. The 
population of Bangladesh is projected to be 172 million by 2020 , with rice and wheat requirements of 36.9 and $1.3 \mathrm{Mt}$, respectively, but with no scope of increasing the area under rice and wheat production (IFPRI, 2012). Therefore, there is a need to increase rice and wheat production by increasing yield and cropping system intensification.

In addition to calorific food security, malnutrition is a major problem in Bangladesh; children and women in general, and $95 \%$ of lactating mothers, are the worst affected (Kabir et al., 2005). From a nutritional standpoint, mungbean is a rich protein source $(24.5 \%)$, two to three folds higher than the protein content of wheat and rice, contains some essential micronutrients, especially $\mathrm{Zn}, \mathrm{Fe}$, and some essential amino acids (especially lysine) that are lacking in rice and wheat (Alam et al., 2017).

The major agricultural crop production systems in Bangladesh are: 1) Transplanted (T.) boro rice (winter)-T. aman rice (monsoon) and 2) wheat$\mathrm{T}$. aman rice cropping systems, which occupies 2.4 and 0.5 Mha, respectively (Ladha et al., 2003; Dawe et al., 2004). Over $85 \%$ of the wheat produced in Bangladesh is grown in sequence with puddled transplanted ( $\mathrm{T}$. aman) rice (Timsina and Connor, 2001). The current T. boro rice-T. aman rice and wheat-T. aman rice cropping systems are not sustainable because of decreasing profitability due to increasing labor and tillage costs, increasing labor scarcity, groundwater depletion, and declining soil fertility.

Agricultural soils in Bangladesh are generally poor in organic matter content due to intensive tillage, removal of crop residues, low use of organic materials and imbalanced fertilizer practices (BARC, 2012). Continuous cultivation of puddled transplanted rice in sequence with upland crops such as wheat led to declining soil organic matter and increasing deficiencies of major nutrients (N, P, K, and $\mathrm{S}$ ) and micronutrients ( $\mathrm{Zn}, \mathrm{Fe}$, and $\mathrm{Mn}$ ) due to over mining from soils (Ladha et al., 2000; Tiwari,
2002). So, alternative practices for rice-based cropping systems are needed which would increase the productivity, and reduce adverse environmental effects. One potential way of achieving this is to switch to conservation agriculture (CA) practices with reduced tillage, inclusion of legume in the rotation, residue retention and crop diversification (Hobbs et al., 2008).

Considering the above facts, a two year ricebased cropping system experiment was conducted in a calcerous soil of Bangladesh to evaluate the effects of reduced tillage, increased cropping intensity, the inclusion of a legume, and rice residue retention on crop growth, yield performance and soil properties.

\section{Materials and Methods}

\subsection{Site description}

The experiment was conducted during 2011-13 at the experimental farm of the Regional Agricultural Research Station (RARS) of Bangladesh Agricultural Research Institute (BARI), Jessore $\left(23^{\circ} 11^{\prime} \mathrm{N}, 89^{\circ} 14^{\prime} \mathrm{E}\right.$ and $16 \mathrm{~m}$ above sea level). The climate at the experimental site is subtropical monsoon with high rainfall during May to October and scanty rainfall during November to April. Annual average rainfall is $1590 \mathrm{~mm}, 90 \%$ of the total rainfall occurs from May to October and the distribution of the rainfall is uneven and unpredictable. Monthly average temperature ranges from $20{ }^{\circ} \mathrm{C}$ in January to $35{ }^{\circ} \mathrm{C}$ in April, with maximum and minimum daily values of $42{ }^{\circ} \mathrm{C}$ and $5{ }^{\circ} \mathrm{C}$ in April-May and January, respectively. Monthly mean solar radiation ranges from $13 \mathrm{MJm}^{-2} \mathrm{~d}^{-1}$ in December to $22 \mathrm{MJm}^{-2} \mathrm{~d}^{-1}$ in May. The soil at the experimental site is a calcareous brown clay loam of the High Ganges River Floodplain (BARC, 2012). Soil texture is clay loam to a depth of at least $120 \mathrm{~cm}$, but clay content declines from $38 \%$ in the topsoil to $26-28 \%$ at $60-120 \mathrm{~cm}$. The topsoil is slightly alkaline $(\mathrm{pH}$ 7.7-7.8) and with low soil organic $\mathrm{C}$ content of 1.0\% (Alam et al., 2017; 2018). 


\subsection{Experimental design}

The experiment was laid out in a split plot design with three replications. Four cropping system/establishment method treatments (CSE) were considered as main plots as follows:

CSE1: T. boro-T. aman (control)

- both crops transplanted into puddled soil

CSE2: CT wheat-CT mungbean-T. aman - conventional tillage (CT) for wheat and mungbean which were sown using a power tilleroperated seeder (PTOS) in a single pass with full tillage; aman transplanted into puddled soil

CSE3: CT wheat-CT mungbean-CTDS aman

- conventional tillage (CT) for all crops including dry seeded (DS) aman, using a PTOS in a single pass with full tillage

CSE4: ST wheat-ST mungbean-STDS aman - as for CSE3 but using strip tillage (ST) for all crops

Two levels of aman residue retention such as removed at ground level (-R), and partial retention $(+\mathrm{R}, 40 \mathrm{~cm}$ of standing stubble)-were compared as sub-plot treatments.

\subsection{Crop management}

All the crops were well managed following recommended management practices. Further details on management of the wheat, mungbean and T. boro was provided as described by Alam et al. (2017), while management of the dry seeded and puddled transplanted aman rice was outlined by Alam et al. (2018).

\subsection{Crop monitoring}

\subsubsection{Crop growth}

Tiller density and biomass were determined at the start of tillering, mid-tillering (MT), panicle initiation (PI) (only for rice), anthesis and physiological maturity (PM) stages on plants collected from $2 \times 0.5 \mathrm{~m}$ rows in two locations in each sub plot (for wheat and DSR) and from $2 \times$ $0.6 \mathrm{~m}$ rows in two locations for transplanted rice. The total number of tillers in each sample was counted. The plants were dried in an oven at 70 ${ }^{\circ} \mathrm{C}$ for 3-5 days until the weight was constant and weighed. Tiller density (no. $\mathrm{m}^{-2}$ ) and dry biomass $\left(\mathrm{t} \mathrm{ha}{ }^{-1}\right.$ ) were calculated by dividing the total number of tillers and total biomass by the sample area $\left(0.4 \mathrm{~m}^{2}\right.$ for wheat and DSR, $0.48 \mathrm{~m}^{2}$ for transplanted rice).

\subsubsection{Yield}

Grain yield was determined by harvesting a 16 $\mathrm{m}^{2}$ (for rice and wheat) and $15.6 \mathrm{~m}^{2}$ (mungbean) area in the centre of each sub-plot. The grain was manually threshed and fresh grain and straw weights were determined. Grain moisture content was determined on $3 \times 100$ grain sub-samples using a grain moisture meter (Model: GMK303RS) at the time of weighing. Fresh grain yield was converted to grain yield $\left(\mathrm{t} \mathrm{ha}^{-1}\right)$ at $12 \%$ moisture content (for wheat), $14 \%$ (for rice) and $10 \%$ (for mungbean) using the following formula:

Grain yield $\left(\mathrm{tha}^{-1}\right)$ at $\mathrm{x} \%$ moisture content $=$

$(100-$ moisture $\%) \times$ Fresh grain weight $(\mathrm{kg}) \times 10000$

$$
(100-x) \times 16 \text { or } 15.6 \times 1000
$$

Where, $\mathrm{x}$ is adjusted moisture (for rice, wheat and mungbean @ 14, 12 and 10\%, respectively)

\subsection{System rice equivalent yield}

Rice equivalent yield (REY) of wheat and mungbean was calculated from the grain yield and price of each crop using the formula:

$\operatorname{REY}\left(\operatorname{crop}_{\chi}\right)=Y_{\chi}\left(P_{\chi} / P_{r}\right)$

where, $Y_{\chi}$ is the yield of crop ' $\mathrm{x}$ " $\left(\mathrm{t}\right.$ grain $\mathrm{ha}^{-1}$ at the above moisture content for that crop), $P_{\chi}$ is the price of crop ' $\mathrm{x}$ ' $\left(\mathrm{USD} \mathrm{t} \mathrm{t}^{-1}\right)$ and $P_{r}$ is the price of rice (Biswas et al., 2006).

\subsection{System energy output}

Total system energy output was estimated using energy equivalents as suggested by many scientists (Khan and Hossain, 2007; Shahin et al., 2008). The energy output was calculated by totalling the energy value of both the main product and by-products. 


\subsection{Soil properties}

\subsubsection{Soil water tension}

Soil water tension (SWT, $\mathrm{kPa}$ ) was determined daily at 9 am at depths of $7.5,22.5,37.5,52.5$ and $75 \mathrm{~cm}$ for wheat and mungbean, and 7.5 , $22.5,37.5 \mathrm{~cm}$ for DSR aman rice, throughout the season, using vacuum gauge tensiometers (IRROMETER). Soil tension was determined after correcting for the head of water in the tensiometer as follows (Alam, 2016):

soil tension $(\mathrm{kPa})=$

$\frac{\text { Tensiometer reading }(\mathrm{kPa})-\rho \mathrm{hg}}{100}$

Where, $\rho=$ the density of water $\left(1 \mathrm{~g} \mathrm{~cm}^{-3}\right)$

$\mathrm{h}=$ height of tensiometer $(\mathrm{m})$

$\mathrm{g}=$ acceleration due to gravity $\left(9.8 \mathrm{~ms}^{-2}\right)$.

\subsubsection{Bulk density}

Bulk density of the soil profile was determined by digging a pit in buffer areas during the first wheat crop. Soil samples were collected at depths of 0-15, 15-30, 30-60, 60-90 and 90-120 $\mathrm{cm}$ using steel cylinders (diameter $5.5 \mathrm{~cm}$, length $4.3 \mathrm{~cm}$ ). The rings were hammered into the sides of the pits. The cores were carefully trimmed, cleaned, weighed, oven-dried at $105{ }^{\circ} \mathrm{C}$, then reweighed. Bulk density was calculated using the formula:

Bulk density $\left(\mathrm{g} \mathrm{cm}^{-3}\right)=$ Weight of oven dried soil (g)

Volume of core $\left(\mathrm{cm}^{3}\right)$

\subsection{Weather data}

Daily maximum and minimum temperature, rainfall and sunshine hours during the experimental period were collected from the weather station, Bangladesh Meteorological Department (Jessore) located about $5 \mathrm{~km}$ from the experimental site. Long term weather records (1948 to 2010) were also acquired from the same weather station. Solar radiation was calculated from daily sunshine hours using the Angstrom Formula (Sys et al,. 1991).

\subsection{Statistical analysis}

Data were analyzed by ANOVA (using Crop Stat 7.2) to evaluate differences between treatments, and the means were separated using least significant difference (LSD) at the 5\% level of significance $(\mathrm{p}<0.05)$.

\section{Results}

\subsection{Crop environment}

Monthly mean rainfall, temperature, sunshine hour and solar radiation for the crops wheat, $\mathrm{T}$. boro, mungbean and aman rice are presented in Figs $1 \mathrm{a}, \mathrm{b}$ and $2 \mathrm{a}-\mathrm{d}$. The total amount of rainfall in both the year were also lower than the long term average (Figs. 1a, b; 2a). Monthly mean daily maximum and minimum temperatures in both seasons were usually lower than the longterm averages, and the second season was generally cooler than the first season (by $3-5{ }^{\circ} \mathrm{C}$ in November and January, with several frost days in January) (Fig. 2b). Mean monthly daily sunshine hours were much low compared to that of the long term average (by $30-50 \%$ in November-January), and lower in 2011-2012 than in 2012-2013 in November-January (Fig. 2c). Each season, solar radiation during the grain filling period (Feb-Mar/April in wheat and $\mathrm{T}$. boro) was much high than that during the vegetative stage. Sunshine hours and solar radiation during 2012 and 2013 aman crops were lower than the long term average throughout the season (Fig. 2d).

\subsection{Crop performance}

\subsubsection{Wheat}

\subsubsection{Tiller density}

There was no significant effect of crop establishment method on tiller density at any stage, but rice residue retention had significant but variable effects on tiller density (Figs. 3a-d). In 2011-2012, tiller density increased to 584 tillers $\mathrm{m}^{-2}$ at $35 \mathrm{DAS}$, and then declined to 421 tillers $\mathrm{m}^{-2}$ at anthesis (28\% tiller mortality), with little further change thereafter. On the other hand, in 2012-2013, tiller density was lower $(16 \%)$ with rice residues retained than removed, and this was also the case at mid tillering (MT). However, from MT to anthesis tiller mortality was higher with residues (19\%) than without 
residues $(7 \%)$ which resulted in significantly higher tiller density in the residue retained treatments at anthesis and maturity. Tiller density was always lower in 2012-2013 than in the previous year, with final tiller densities at PM of 317 and $404 \mathrm{~m}^{-2}$ in 2012-2013 and 20112012, respectively.
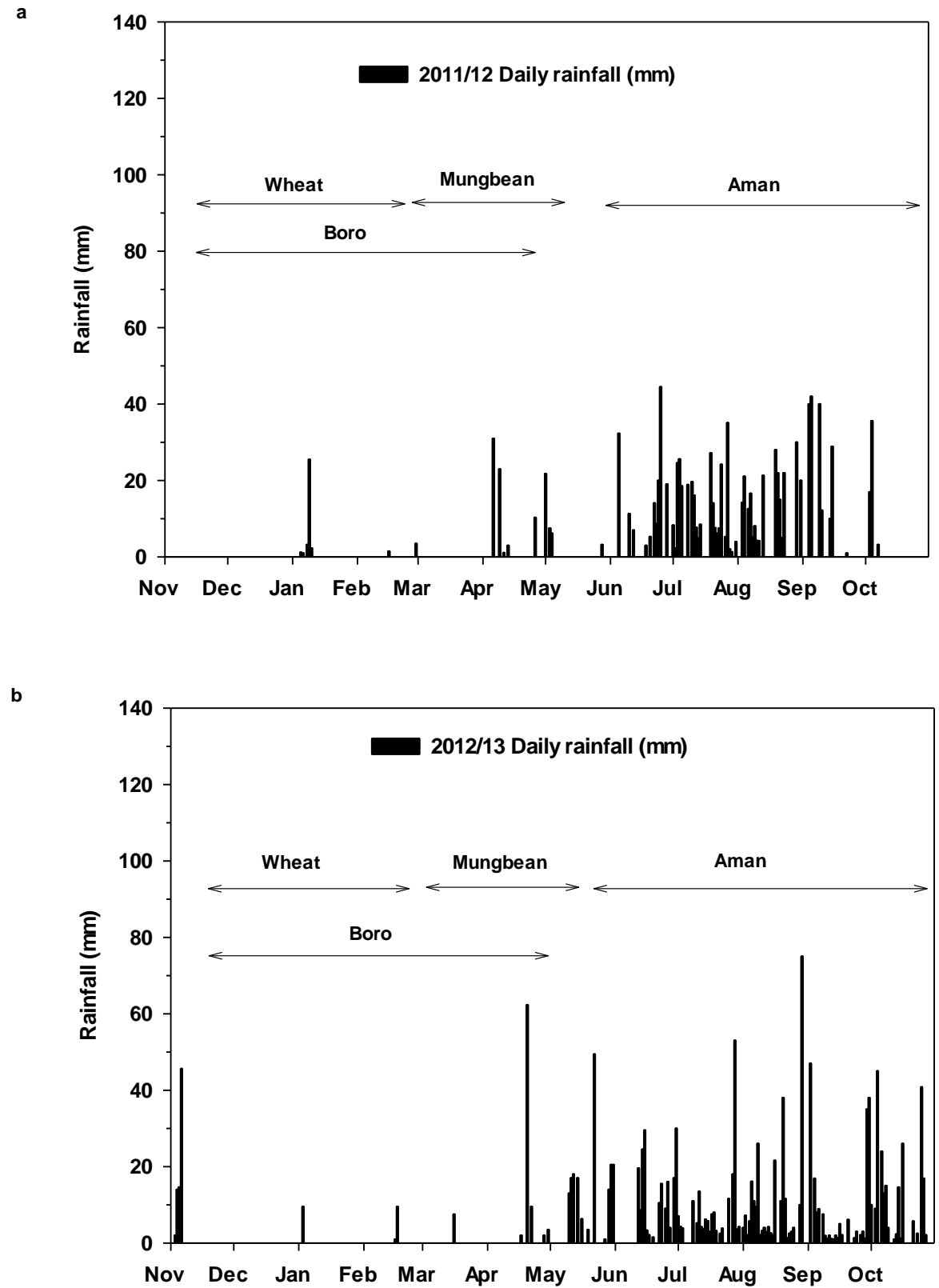

Figure 1. Distribution of rainfall at the experimental site in (a) 2011-2012 and (b) 2012-2013. 

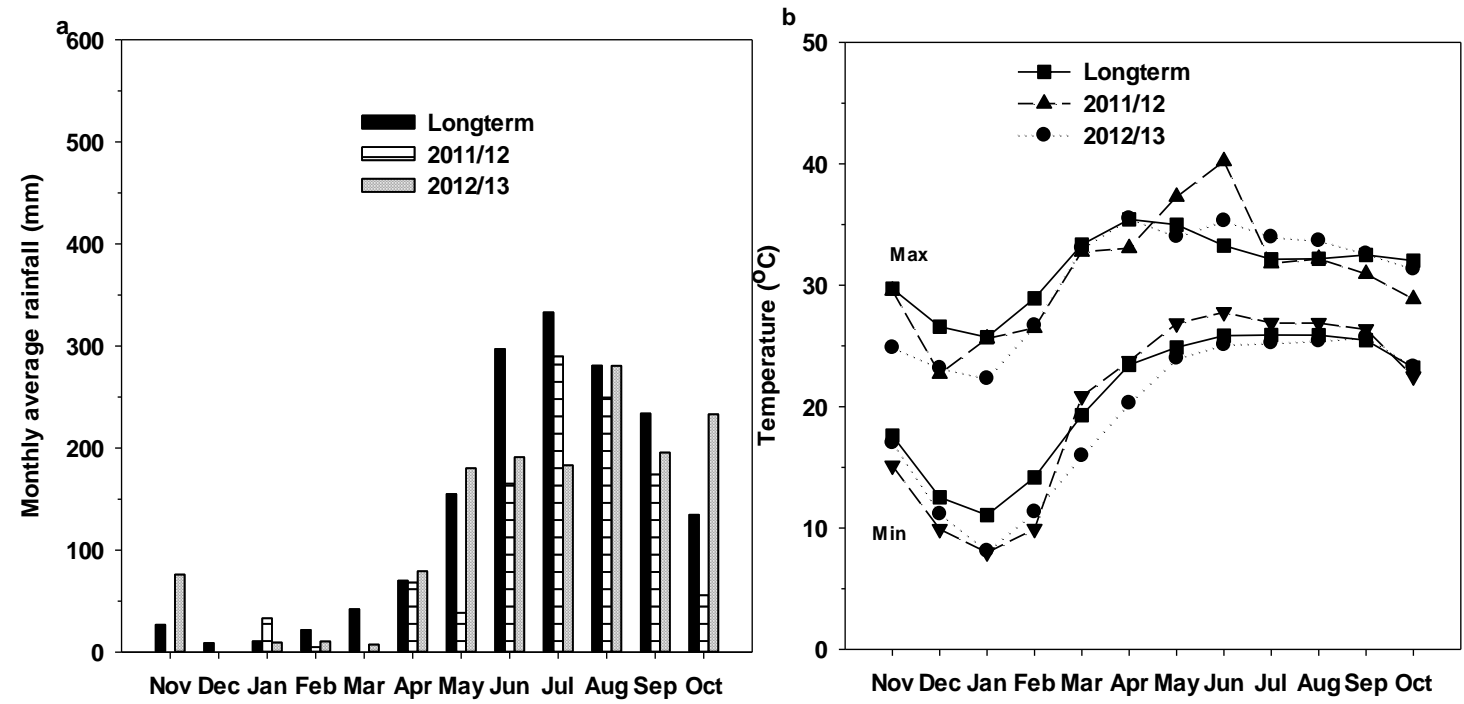

c
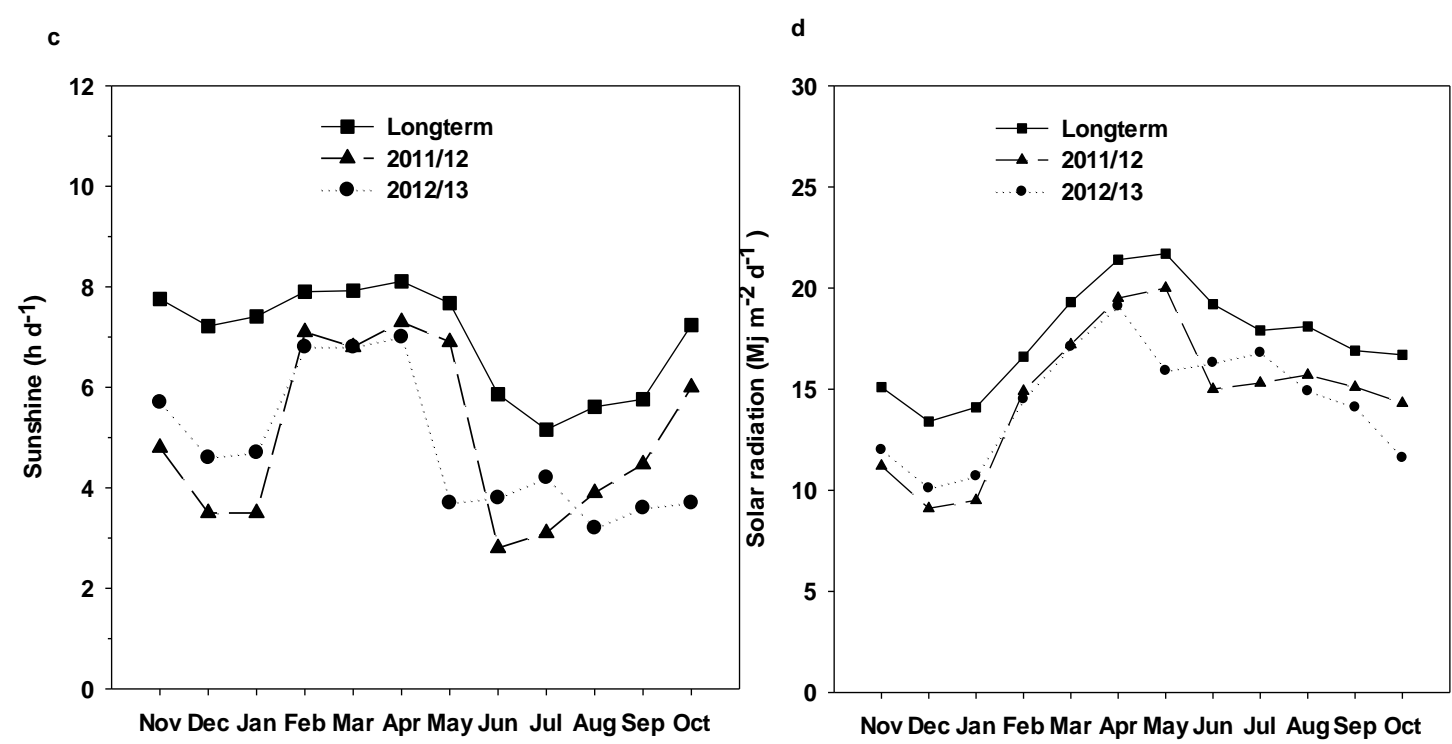

Figure 2. (a) Monthly rainfall (mm), (b) monthly mean maximum and minimum temperature,(c) monthly mean daily sunshine hours, (d) monthly mean solar radiation during the 2011-2012 and 2012-2013 crop seasons in comparison to the long term (1948-2010) at the Bangladesh Meteorological Department station at Jessore. 

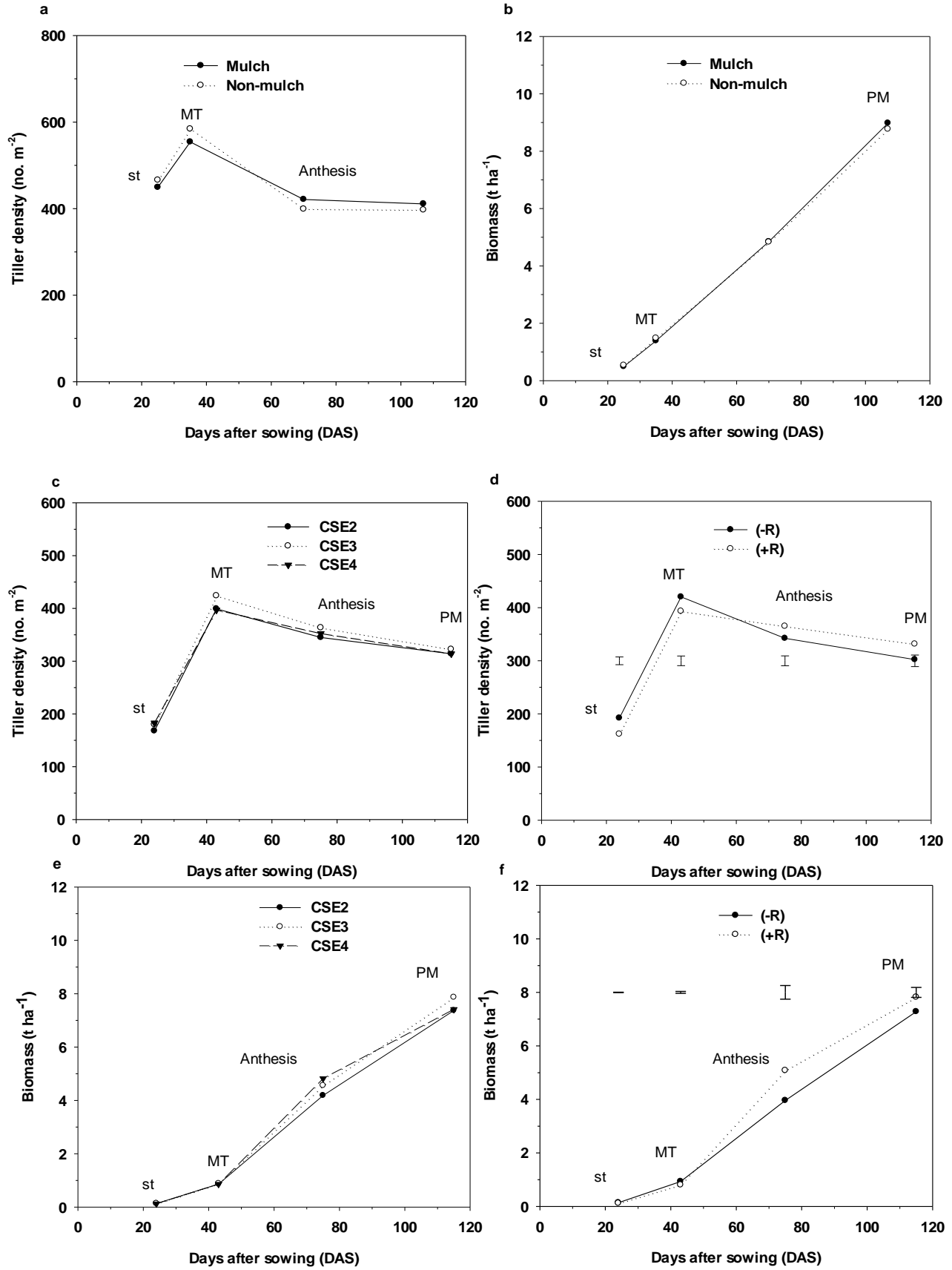

Figure 3. Effect of crop establishment method and rice residue retention on $(a, b)$ tiller density and biomass production in 2011-2012, (c,d) tiller density in 2012-2013, and (e,f) biomass production in 2012-2013 during wheat season (vertical bars are LSD ( $\mathrm{p}=0.05)$ for comparing treatment means within sampling date). 


\subsubsection{Biomass}

As for tiller production, there was no significant effect on above ground biomass (Figs. 3e, f). In 2011-2012, the average rate of biomass production was $69 \mathrm{~kg} \mathrm{ha}^{-1} \mathrm{~d}^{-1}$ between sowing and anthesis, and $109 \mathrm{~kg} \mathrm{ha}^{-1} \mathrm{~d}^{-1}$ between anthesis and PM. In 2012-2013, the rate of biomass accumulation was significantly higher without straw $\left(23 \mathrm{~kg} \mathrm{ha}^{-1} \mathrm{~d}^{-1}\right)$ from establishment to MT than with straw $\left(20 \mathrm{~kg} \mathrm{ha}^{-1} \mathrm{~d}^{-1}\right)$. From MT to anthesis, the biomass accumulation rate was significantly higher with residues retained (146 $\left.\mathrm{kg} \mathrm{ha}^{-1} \mathrm{~d}^{-1}\right)$ to than without (110 $\left.\mathrm{kg} \mathrm{ha}^{-1} \mathrm{~d}^{-1}\right)$, while rates were similar in both treatments from anthesis to PM stage $\left(73 \mathrm{~kg} \mathrm{ha}^{-1} \mathrm{~d}^{-1}\right)$. The net result was significantly higher in final total biomass $\left(7.8 \mathrm{t} \mathrm{ha}^{-1}\right)$ with residues retained than with residues removed $\left(7.3 \mathrm{t} \mathrm{ha}^{-1}\right)$. Total biomass at anthesis $\left(5.1 \mathrm{t} \mathrm{ha}^{-1}\right)$ with residue retention was similar to total biomass in both treatments in 2011-2012 (4.8 $\left.\mathrm{t} \mathrm{ha}^{-1}\right)$. At PM, total biomass with residue retention was also higher in 2011-12 (8.9 $\left.\mathrm{t} \mathrm{ha}^{-1}\right)$ than in both treatments in 2012-2013 (7.8 t $\left.\mathrm{ha}^{-1}\right)$.

\subsubsection{Aman rice}

\subsubsection{Tiller density}

Tiller density of DSR was significantly higher than that of PTR at the vegetative stage in both the years, with the maximum observed difference at MT ( 836 tillers $\mathrm{m}^{-2}$ in 2012 and $\sim 919$ tillers $\mathrm{m}^{-2}$ in 2013, respectively) (Fig. 4a, b). The rate of tiller mortality in DSR was very high ( 47\% in 2012 and $~ 59 \%$ in 2013) between MT and anthesis, compared with mortality in PTR ( 31\% in 2012 and $~ 39 \%$ in 2013) between PI and anthesis. Tiller mortality with both establishment methods was higher in 2013 than in 2012 (49 and 39\% in DSR and PTR, respectively). At $\mathrm{PM}$, tiller density averaged 246 and $347 \mathrm{~m}^{-2}$ in PTR and DSR, compared with 241 and $403 \mathrm{~m}^{-2}$ in 2012, respectively. Tillage method had no effect on tiller density of DSR in the wheat-mung-rice system, and cropping system had no effect on tiller density of PTR. There were no effects of aman residue management on tiller density.

\subsubsection{Biomass}

As in 2012, early biomass accumulation was greater in DSR (73 kg ha ${ }^{-1} \mathrm{~d}^{-1}$ in 2012 and $83 \mathrm{~kg}$ $\mathrm{ha}^{-1} \mathrm{~d}^{-1}$ in 2013) than that in PTR $\left(57 \mathrm{~kg} \mathrm{ha}^{-1} \mathrm{~d}^{-1}\right.$ in 2012 and $64 \mathrm{~kg} \mathrm{ha}^{-1} \mathrm{~d}^{-1}$ in 2013), resulting in significantly higher biomass at MT in DSR (Figs. 4 c,d). However, between MT and anthesis, growth rate was greater in PTR $(315 \mathrm{~kg}$ $\mathrm{ha}^{-1} \mathrm{~d}^{-1}$ in 2012 and $327 \mathrm{~kg} \mathrm{ha}^{-1} \mathrm{~d}^{-1}$ in 2013) than DSR (99 kg ha- $\mathrm{d}^{-1}$ in 2012 and $92 \mathrm{~kg} \mathrm{ha}^{-1} \mathrm{~d}^{-1}$ in 2013), resulting in similar biomass at anthesis. The net result was similar for final biomass in PTR and DSR (mean $10.3 \mathrm{t} \mathrm{ha}^{-1}$ in 2013) compared with $9.7 \mathrm{t} \mathrm{ha}^{-1}$ in 2012. Tillage method had no effect on biomass of DSR at any stage in the wheat-mungbean-rice system, and cropping system had no effect on biomass of PTR. There were no effects of residue management on biomass in any of the year.

\subsection{Rice equivalent system yield}

There were no significant interactions between cropping system/establishment method on rice equivalent system yield each year (Table 1). Furthermore, there were no significant CSE x R $\mathrm{x}$ year interactions, therefore, it is valid to compare the treatment means averaged over the 2 years. There was a consistent trend for higher rice equivalent system yield of the three wheatmungbean-aman systems (CSE 2, 3, 4) than that of the boro-aman system (CSE1), with significant differences in the first year and when the data were pooled over the two years (means of 14.6-15.0 $\mathrm{t} \mathrm{ha}^{-1}$ in CSE 2, 3, 4 compared with $13.4 \mathrm{t} \mathrm{ha}^{-1}$ in CSE 1). There was also a trend for higher system yield with aman rice residue retention with significant differences in the second year and when averaged over the two years (14.1 vs $14.7 \mathrm{t} \mathrm{ha}^{-1}$ for residues removed or retained, respectively).

\subsection{Energy output (grain, harvested straw)}

There was no interactions between CSE and aman residue management on energy output of any crop each year, not on the total system, and there was no significant CSE $x$ R $x$ year interaction (Table 2). Energy output of the boroaman system (mean $354 \mathrm{GJ} \mathrm{ha}^{-1}$ over the 2 years) 
was significantly higher (by an average of around $20 \%$ ) than of the wheat-mungbean-aman systems each year. Removal of aman rice residues also resulted in higher energy output
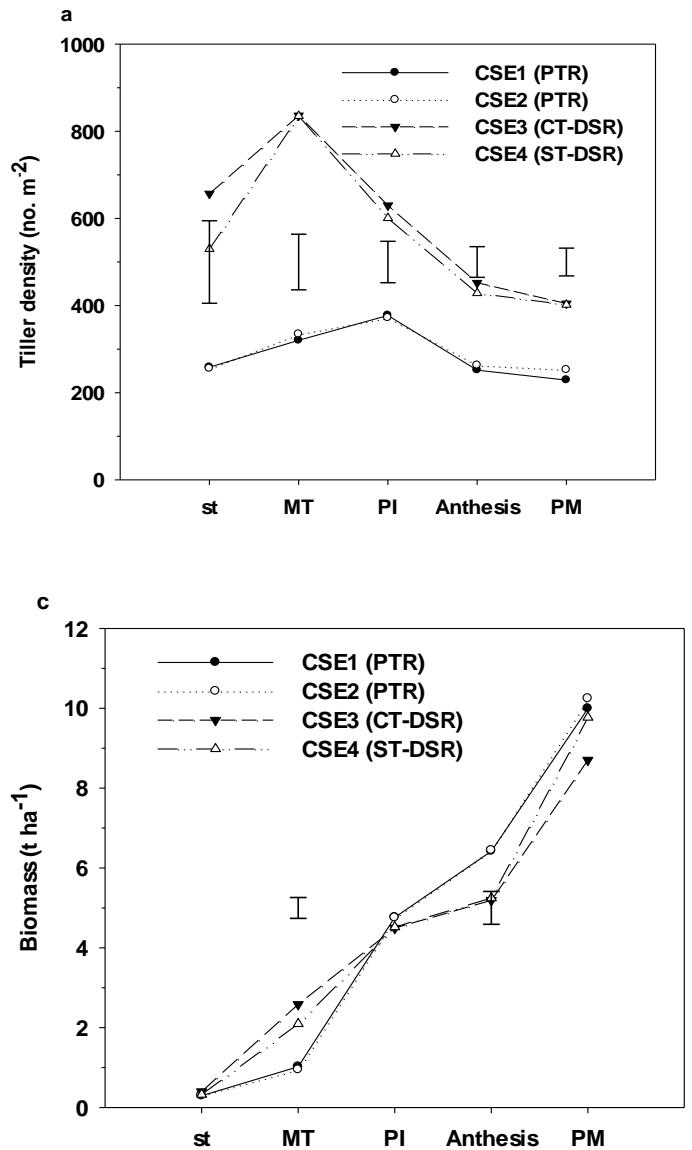

each year (by about $10 \%$ ) due to the fact that the energy value of the retained residues was not included as an energy output.
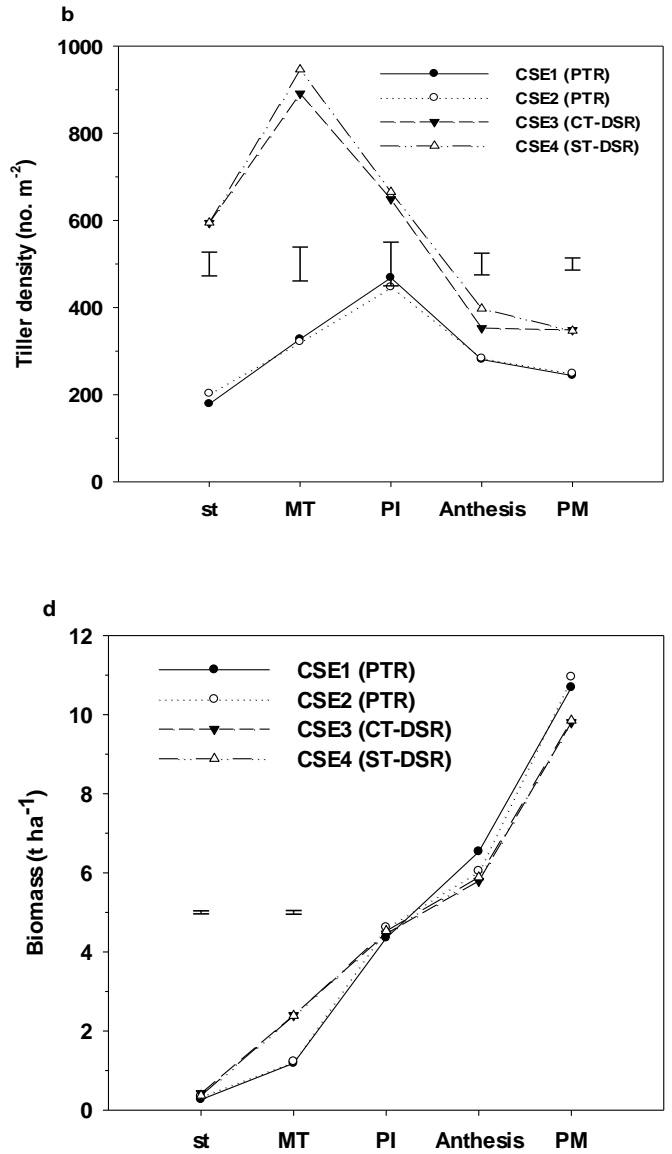

Figure 4. Effect of crop establishment method on (a) tiller density 2012 (b) tiller density 2013, (c) biomass production 2012, and (d) biomass production 2013 of aman rice (vertical bars are $\mathrm{LSD}_{0.05}$ for comparing main treatment effects at each stage).

\subsection{Soil properties change}

\subsubsection{Soil water tension}

\subsubsection{Wheat}

There were significant interactions between CSE, residue treatment and soil depth on soil water tension (SWT) at different dates of with very small lsd $(0.8 \mathrm{kPa})$. For simplicity, the data for the residue retained and removed treatments are presented in two separate figures for CSE3
(Figs. 5a-d). As in 2011-12, the soil dried fastest nearest the surface and the rate of soil drying decreased as depth increased. Throughout the wheat season, the degree of soil drying at 52.5$75 \mathrm{~cm}$ was small, with soil tension never exceeding $25 \mathrm{kPa}$. There was a trend for faster soil drying with residues removed, more so in the top soil, but the differences were never significant. The degree of soil drying at $22.5 \mathrm{~cm}$ was less in 2012-2013 than in 2011-2012. 
Table 1. Effect of CSE and rice residue retention on yield of individual crops and on annual cropping system rice equivalent yield ( $\mathrm{t}$ ha ${ }^{-1}$ ) during 2011 12 and 2012-13, and averaged over the 2 years.

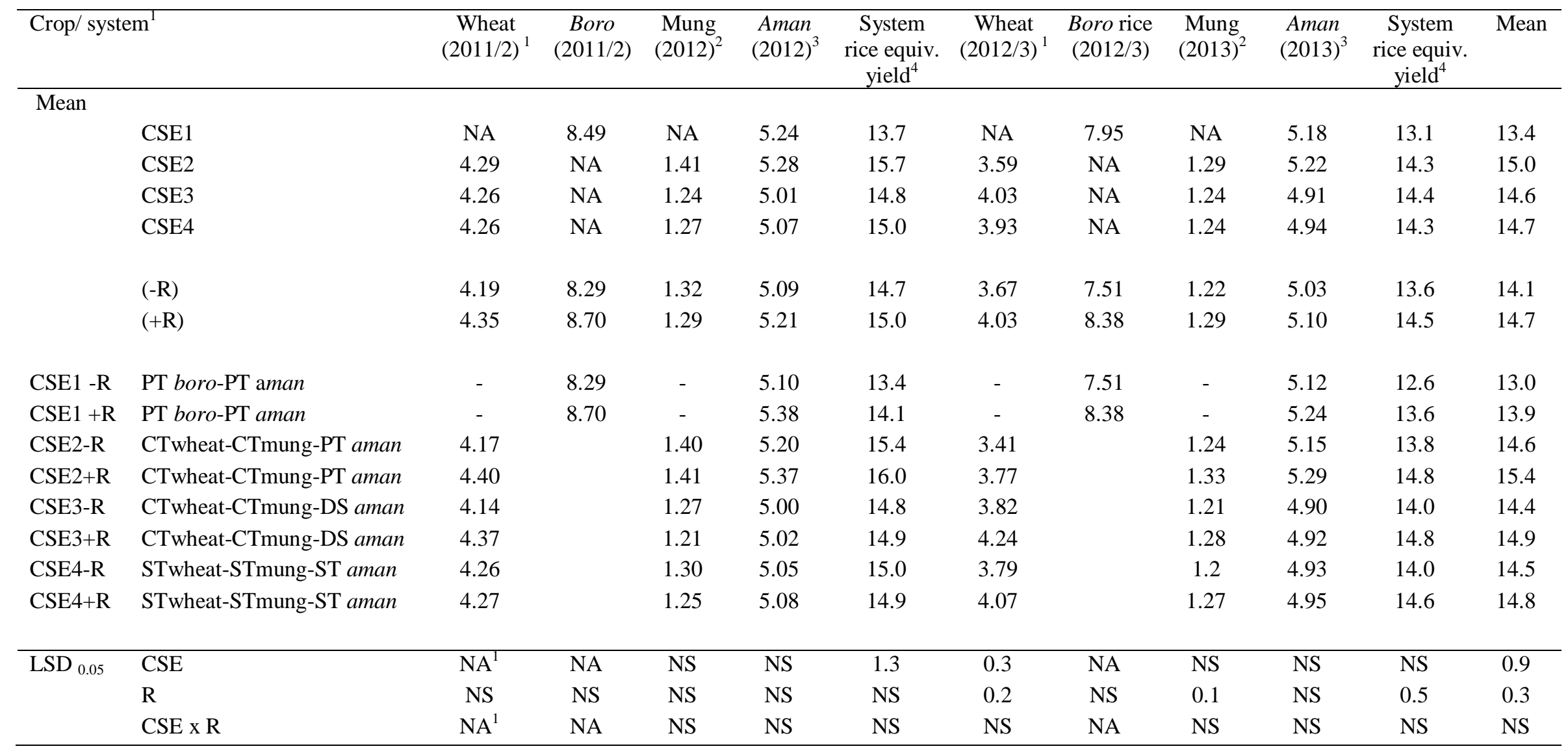

*NA=Not applicable NS $=$ Non significant 
Table 2. Effect of CSE and rice residue management on individual crop and annual cropping system energy output (GJ ha ${ }^{-1}$ ) during $2011-12$ and $2012-$

13 and averaged over both years.

\begin{tabular}{|c|c|c|c|c|c|c|c|c|c|c|c|c|}
\hline \multicolumn{2}{|c|}{ Crop/system ${ }^{1}$} & $\begin{array}{c}\text { Wheat } \\
(2011 / 2)^{1}\end{array}$ & $\begin{array}{c}\text { Boro } \\
(2011 / 2)\end{array}$ & $\begin{array}{l}\text { Mung } \\
(2012)^{2}\end{array}$ & $\begin{array}{c}\text { Aman } \\
(2012)^{3}\end{array}$ & $\begin{array}{l}\text { System } \\
\text { energy } \\
\text { output }^{4}\end{array}$ & $\begin{array}{c}\text { Wheat } \\
(2012 / 3)^{1}\end{array}$ & $\begin{array}{c}\text { Boro } \\
(2012 / 3)\end{array}$ & $\begin{array}{l}\text { Mung } \\
(2013)^{2}\end{array}$ & $\begin{array}{c}\text { Aman } \\
(2013)^{3}\end{array}$ & $\begin{array}{l}\text { System } \\
\text { energy } \\
\text { output }^{4}\end{array}$ & Mean \\
\hline \multicolumn{13}{|l|}{ Means } \\
\hline & CSE1 & NA & 238 & NA & 142 & 380 & NA & 185 & NA & 143 & 329 & 354 \\
\hline & CSE2 & 133 & NA & 18 & 144 & 296 & 113 & NA & 17 & 146 & 276 & 286 \\
\hline & CSE3 & 140 & NA & 16 & 131 & 287 & 124 & NA & 15 & 131 & 270 & 279 \\
\hline & CSE4 & 134 & NA & 17 & 136 & 287 & 113 & NA & 15 & 132 & 260 & 274 \\
\hline & $(-\mathrm{R})$ & 134 & 232 & 17 & 159 & 331 & 111 & 176 & 16 & 156 & 295 & 313 \\
\hline & $(+\mathrm{R})$ & 137 & 244 & 17 & 117 & 293 & 122 & 195 & 16 & 120 & 273 & 283 \\
\hline CSE1 -R & PT Boro-PT Aman & - & 232 & - & 162 & 394 & - & 176 & - & 163 & 339 & 367 \\
\hline $\mathrm{CSE} 1+\mathrm{R}$ & PT Boro-PT Aman & - & 244 & - & 121 & 365 & - & 195 & - & 124 & 319 & 342 \\
\hline CSE2-R & CTwheat-CTmung-PT aman & 126 & & 18 & 170 & 314 & 108 & & 17 & 165 & 289 & 302 \\
\hline CSE2+R & CTwheat-CTmung-PT aman & 140 & & 18 & 119 & 277 & 118 & & 17 & 128 & 263 & 270 \\
\hline CSE3-R & CTwheat-CTmung-DS aman & 138 & & 17 & 150 & 304 & 118 & & 15 & 147 & 280 & 292 \\
\hline $\mathrm{CSE} 3+\mathrm{R}$ & CTwheat-CTmung-DS aman & 143 & & 16 & 112 & 270 & 131 & & 15 & 116 & 261 & 266 \\
\hline CSE4-R & STwheat-STmung-ST aman & 139 & & 17 & 156 & 312 & 109 & & 15 & 150 & 273 & 293 \\
\hline CSE4+R & STwheat-STmung-ST aman & 130 & & 16 & 116 & 262 & 118 & & 15 & 115 & 248 & 255 \\
\hline \multirow[t]{3}{*}{$\mathrm{LSD}_{0.05}$} & CSE & $\mathrm{NA}^{1}$ & NA & 2.8 & NS & 28.3 & 6.2 & NA & 1.7 & NS & 28.1 & 25.1 \\
\hline & $\mathrm{R}$ & NS & NS & NS & 6.3 & 10.1 & 4.1 & NS & NS & 4.7 & 9.9 & 6.7 \\
\hline & CSE x R & $\mathrm{NA}^{1}$ & NA & NS & NS & NS & NS & NA & NS & NS & NS & NS \\
\hline
\end{tabular}

*NA=Not applicable $;$ NS=Non significant

$1 \mathrm{~kg}$ rice grain, wheat grain, mungbean grain, rice straw, wheat straw and mungbean biomass produced energy of 14.7, 14.7, 15.5, 15.6, 15.8 and 12.5

MJ (adopted from Khan and Hossain, 2007 and Shahin et al., 2008). 


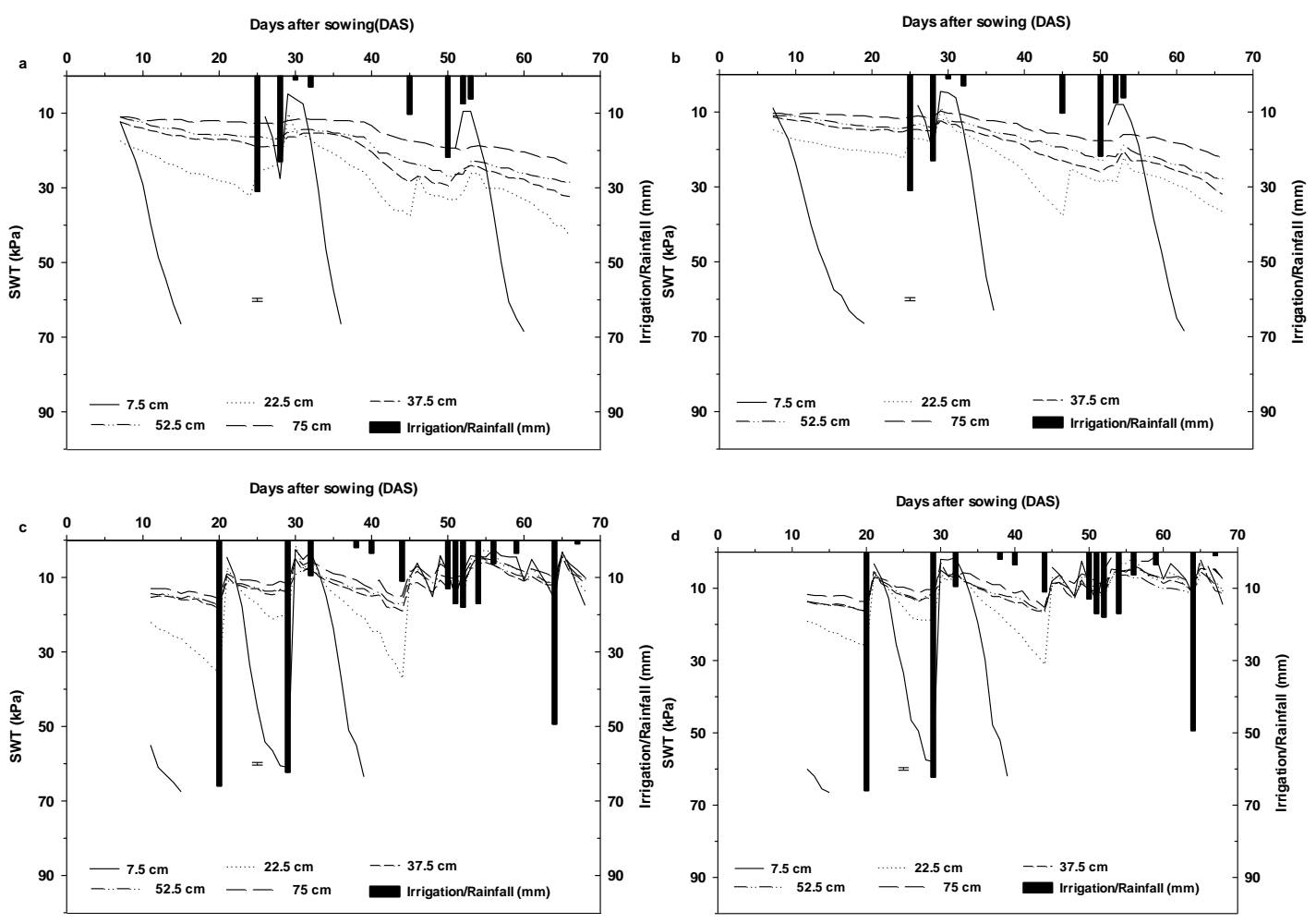

Figure 6. Soil water tension status at 7.5, 22.5, 37.5, 52.5 and $75 \mathrm{~cm}$ depth in conventional tillage (a) without residue 2012 (b) with residue 2012 (c) without residue 2013 (b) with residue 2013 treatment during mungbean season (Vertical bars are $\mathrm{LSD}_{0.05}$ for comparing different depths).

\subsubsection{Mungbean}

There were significant interactions between CSE, residue treatment and soil depth on soil water tension (SWT) at many measuring dates, with very small lsd (0.8 $\mathrm{kPa}$ in 2012 and $0.7 \mathrm{kPa}$ in 2013). For simplicity, the data for the residue retained and removed treatments are presented in two separate figures for CSE3 only (Figs. 6a-d). In 2012, the soil dried fastest nearest the surface and the rate of soil drying decreased as depth increased. Throughout the mung season, the degree of soil drying below $22.5 \mathrm{~cm}$ was small, with soil tension never exceeding $30 \mathrm{kPa}$. There was a slight tendency for the soil to dry more slowly with rice residue retention than removal after irrigation or rainfall in the upper soil layers, but the differences were never significant.

\subsubsection{Soil bulk density}

There were no significant two-or three-way interactions between cropping system/ establishment method, residue management or depth on bulk density after two years (after harvest of the second aman crop). Nor were there any significant effects of CSE or residue management on bulk density (Table 3). Bulk density at $5-10 \mathrm{~cm}\left(1.33 \mathrm{~g} \mathrm{~cm}^{-3}\right)$ was significantly lower than bulk density at $0-5$ and $10-15 \mathrm{~cm}\left(1.39-1.40 \mathrm{~g} \mathrm{~cm}^{-3}\right)$. 
Table 3. Effects of cropping system/establishment method and aman residue management on bulk density after 2 years.

\begin{tabular}{lc}
\hline Crop/system & \\
\hline Cropping system/establishment method (CSE) means & $\left.\mathrm{BD}^{1} \mathrm{~g} \mathrm{~cm}^{-3}\right)$ \\
CSE1 & 1.38 \\
CSE2 & 1.42 \\
CSE3 & 1.32 \\
CSE4 & 1.38 \\
Residue management (R) means & \\
$(-\mathrm{R})$ & 1.38 \\
(+R) & 1.37 \\
Depth (D) means & \\
$0-5 \mathrm{~cm}$ & 1.39 \\
$5-10 \mathrm{~cm}$ & 1.33 \\
$10-15 \mathrm{~cm}$ & 1.40 \\
LSD 0.05 & \\
CSE & $\mathrm{NS}$ \\
R & $\mathrm{NS}$ \\
Depth & 0.04 \\
CSExR & $\mathrm{NS}$ \\
CSExD & $\mathrm{NS}$ \\
RxD & $\mathrm{NS}$ \\
CSExRxD & $\mathrm{NS}$ \\
\hline
\end{tabular}

$* N S=$ Not significant $;{ }^{1}$ CSE1 $=T$. boro-T. aman (puddle transplanted); CSE2 = CTwheat-CTmung-T. aman (puddled transplanted); CSE3=CTwheat-CTmung-CT aman (dry seeded); CSEE4=STwheat-

STmung-ST aman (dry seeded)

\section{Discussion}

\subsection{Effect of seasonal conditions on crop performance}

\subsubsection{Wheat}

The lower biomass in 2012-13 was associated with lower tiller production. The lower tiller production appears to be due to the much lower plant density (170 and 119 plants $\mathrm{m}^{-2}$ in 2011-12 and 2012-13 respectively), and possibly also due to the cooler weather during the tillering stage in 2012-13 (Fig. 2b), which ultimately led to lower spike density, more so in the non-mulched treatment. The reasons for the lower biomass at anthesis in the without residue retention treatment in 2012-13 are not known. Biomass accumulation between anthesis and PM was much low in both the treatments in 2012-13 (2.7 and $3.5 \mathrm{t} \mathrm{ha}^{-1}$ in the residue retained and removed treatments respectively) than that in 2011-12 (4.1 $\left.\mathrm{t} \mathrm{ha}^{-1}\right)$. The reasons for the difference in growth rate between anthesis and PM between years are also not clear as mean February temperatures and solar radiation were similar during this period.Total biomass production $(7.3$ and $7.8 \mathrm{t}$ $\mathrm{ha}^{-1}$ ) and grain yield (3.7-4.3 $\mathrm{t} \mathrm{ha}^{-1}$ ) were also consistent with the findings of Islam et al. (2013) for irrigated BARI gom 26.

\subsubsection{Aman rice}

Temperature was generally favorable for aman production each year, with daily mean temperature ranging from 24 to $35^{\circ} \mathrm{C}$ in 2012 
and 2013. Basak (2010) reported that the optimum temperature for maximum photosynthesis ranges from 25 to $30{ }^{\circ} \mathrm{C}$ for rice under the climatic conditions of Bangladesh. Within establishment method, crop development, growth, yield and yield components of the aman crops were similar each year, consistent with the similar weather experienced each year in terms of temperature and solar radiation, although total solar radiation during flowering to $\mathrm{PM}$ was $20 \%$ (PTR) and 30\% (DSR) lower in 2013 than in 2012.

\subsection{Effect of cropping system establishment (CSE) methods on crop and system yield}

Crop establishment method had a significant effect on yield of wheat in the second year (after the first aman crop), with lower yield of wheat sown after PTR (3.6 t ha $\left.{ }^{-1}\right)$ than after DSR (4.0 t $\mathrm{ha}^{-1}$ ) established with either conventional or strip tillage. This is consistent with the findings of studies on soils with a history of puddling (converse to the situation in the present study), where cessation of puddling and replacement with DSR results in higher yield of wheat starting with the second or third wheat crop (Jat et al., 2009; Gathala et al., 2011). The increase in yield of wheat grown after DSR in comparison to PTR in other studies has been shown to be associated with improved soil structure in ricewheat system (Gathala et al.,2011; Singh et al., 2014). In contrast to wheat, there was no effect of CSE on yield of mungbean or rice in both the years. Several studies showed no effect of tillage treatments formungbean on yield when grown in a wheat-mungbean-PTR system (Islam et al. 2014). Reports on grain yield of well-managed DSR relative to PTR showed variable results (Kumar and Ladha, 2011). In our study, the grain yield of DSR and PTR were similar each year, consistent with the findings of Sudhir- Yadav et al. (2011) and Bhushan et al. (2007) on a range of soils (sandy to silty loam to clay loam) using safe alternate wetting and drying water management for both establishment methods.

Total system rice equivalent yield (REY) ranged from 12.6 to 16.0 tha $^{-1}$ across years and CSE $\mathrm{x}$ aman residue treatments. There was a consistent trend for highest yield in CSE2 (the wheatmungbean-aman system with PTR), with significantly higher yield than yield of CSE1 (the puddled transplanted boro-aman system) in first year and averaged over two years (by $1.6 \mathrm{t} \mathrm{ha}^{-1}$ ), but similar yield to the wheat-mungbean-aman systems with DSR. The higher REY of CSE2 than CSE1 was due to the higher price received by farmers for mungbean and wheat than for rice, which more than compensated for their lower yields in comparison with the high yield of boro rice.

\subsection{Effect of rice residue retention on crop and system yield}

There was no effect of partial aman straw retention in the first year on any individual crop yield, nor on total system REY. However, in 2012-13, wheat and mungbean yields were slightly but significantly higher with rice straw retention than removed, and as a result, total system REY in that year was also significantly higher (by $0.9 \mathrm{t} \mathrm{ha}^{-1}$ ) with aman residue retention. The improved wheat crop performance with rice straw retention could be due to higher soil water availability in the topsoil. In the present experiment, a considerable amount of straw remained on the surface when wheat was sown into the standing residues using both strip and full tillage with the PTOS in a single pass. The soil dried slightly faster without straw retention than with retention after irrigation or rainfall, consistent with the findings of others (Rahman et al., 2005; Sidhu et al., 2007).The higher tillering and lower tiller mortality in 2012-13 in the straw retained treatment in the present experiment may reflect higher topsoil moisture, which resulted in significantly higher spike density and more grains spike $^{-1}$. The significant response of mungbean to aman straw retention in the second year is difficult to explain. By the time of mungbean sowing, there was little un-decomposed rice straw remaining on the soil surface. There was no effect of aman straw retention on yield of either T.aman or DS aman in any system, nor on yield of T. boro. Other studies in rice-wheat systems in north west India found that yield benefits of rice straw 
incorporation did not appear in rice until the fourth crop (Verma and Bhagat, 1992), or six years (Yadvinder-Singh et al., 2005).

\subsection{Effects of cropping system/establishment method and aman residue retention on soil properties}

There was no significant effect of CSE or aman residue retention on bulk density of the soil profile $(0-5,5-10,10-15 \mathrm{~cm})$ after two complete cropping cycles (4 crops in CSE1, 6 crops in CSE2-4). Other studies have shown differences in bulk density in reduced tillage and conventional tillage in rice-wheat systems after 2 and 4 years (Jat et al., 2009; Gathala et al., 2011). Jat et al. (2009) also reported that the conventional tillage system had higher bulk density in the $10-15$ and $15-20 \mathrm{~cm}$ soil layers after two years due to compaction caused by the repeated wet tillage for rice in a rice-wheat rotation.

\section{Conclusions}

This study has shown that yield of aman crop was not affected by establishment method. Yield of wheat was significantly reduced (by 10\%) when sown after PTR than after DSR. Furthermore, system productivity (rice equivalent yield, REY) was significantly increased (by $10 \%$ or $1.4 \mathrm{t} \mathrm{ha}^{-1}$ ) by intensifying from a boro-aman to awheat-mungbean-aman system. Productivity of the wheat-mungbeanaman systems with PTR (CSE2) or DSR (CSE3) was similar in terms of REY and energy output. Conventional tillage (CT) and strip tillage (ST) did not affect the performance of wheat, mungbean and DS aman in terms of any of the measured crop and cropping system parameters including crop and system yield, and energy output. Partial aman residue retention significantly increased system yield by $(0.6 \mathrm{t} \mathrm{ha}$ ${ }^{1}$ ), averaged over two years, due to consistent trends for higher yields of all crops. Finally, after two years, there was no effect of cropping system/establishment method or partial aman residue retention on bulk density of the top soil. Therefore, well planned cropping system along with proper management system may be useful for sustainable agricultural productivity.

\section{References}

Alam MJ., Humphreys E., Sarkar MAR., SudhirYadav. 2017. Intensification and diversification increase land and water productivity and profitability of rice-based cropping systems on the High Ganges River Floodplain of Bangladesh. Field Crops Research, 209: 10-26.

Alam MJ., Humphreys E., Sarkar MAR., SudhirYadav. 2018. Comparison of dry seeded and puddled transplanted rainy season rice on the High Ganges River Floodplain of Bangladesh. European Journal of Agronomy, 96:120-130.

BARC (Bangladesh Agricultural Research Council). 2012. Fertilizer recommendation guide. BARC, Farmgate, Dhaka 1215. pp. $1-286$.

Basak JK. 2010. Climate change impacts on rice production in Bangladesh: results from a Model. Unnayan Onneshan-The Innovators, Dhanmondi, Dhaka- 1209, Bangladesh. pp. 1-25.

BBS (Bangladesh Bureau of Statistics). 2011. Statistical Year Book of Bangladesh. Planning Division, Ministry of Planning, Government of the People's Republic of Bangladesh. pp. 37.

Begum MEA., D'Haese L. 2010. Supply and demand situations for major crops and food items in Bangladesh. Journal of Bangladesh Agricultural University, 8(1):91-102.

Bhowmik SK., Sarkar MAR., Zaman F. 2012. Effect of spacing and number of seedlings per hill on the performance of Aus rice cv. NERICA 1 under dry direct seeded rice (DDSR) system of cultivation. Journal of Bangladesh Agricultural University, 10(2):191-195. 
Bhushan L., Ladha JK., Gupta RK., Singh S., Tirol-Padre A., Saharawat YS., Gathala M., Pathak H. 2007. Saving of water and labor in rice-wheat systems with notillage and direct seeding technologies. Agronomy Journal, 99: 1288-1296.

Biswas B., Ghosh DC., Dasgupta MK., Trivedi N., Timsina J., Dobermann A. 2006. Integrated assessment of cropping systems in the Eastern Indo-Gangetic plain. Field Crops Research, 99:35-47.

Dawe D., Frolking S., Li, C. 2004. Trends in rice-wheat area in China. Field Crops Research, 87:89-95.

Gathala MK., Ladha JK., Kumar V., Saharawat YS., Kumar V., Sharma PK. 2011. Effect of tillage and crop establishment methods on physical properties of a mediumtextured soil under a seven-year ricewheat rotation. Soil Science Society of American Journal, 75(5):1-12.

Hobbs PR., Sayre K., Gupta R. 2008. The role of conservation agriculture in sustainable agriculture. Philosophical Transactions of the Royal Society of London B: Biological Sciences, 363:543-555.

Hossain A., Teixeira da Silva J A. 2013. Wheat production in Bangladesh: its future in the light of global warming. AoB PLANTS, 5:1-24

IFPRI (International Food Policy Research Institute). 2012. Supply and demand for cereals in Bangladesh 2010-2030. In: Kumar, A. G., Prasad, S. K., Pullabhotla, H. (Eds.), IFPRI Discussion Paper 01186. Environment and Production Technology Division, New Delhi Office. pp. 1-36.

Islam QMS., Miah MAM., Rahman MS., Hossain MS. 2013. Adoption of BARI mung varieties and its constraints to higher production in southern region of Bangladesh. Bangladesh Journal of Agricultural Research, 38(1):85-96.
Islam MA., Bell1 RW., Haque ME., Johansen C., Jahiruddin M., Vance W. 2014. Conservation agriculture in rice-based cropping systems: Its effect on crop performance. In: Vance, WH., Bell RW., Haque ME. (eds.), Proceedings of the Conference on Conservation Agriculture for Smallholders in Asia and Africa, 7-11 December 2014, Mymensingh, Bangladesh. pp. 135-136.

Jat ML., Gathala MK., Ladha JK., Saharawat YS., Jat AS., Vipin K., Sharma SK., Kumar V., Gupta RK. 2009. Evaluation of precision land leveling and double zerotill systems in the rice-wheat rotation: Water use, productivity, profitability and soil physical properties. Soil and Tillage Research, 105:112-121.

Kabir MJ., Hafeez ASMG., Haque N., Kabir MA., Rahaman MA. 2005. Comparative economic study of profitability among maize and its competitive crops. Bangladesh Journal of Agricultural Research, 30(1):137-149.

Khan MA., Hossain SMA. 2007. Study on energy input, output and energy use efficiency of major jute based cropping pattern. Bangladesh Journal of Scientific and Industrial Research, 42(2): 195-202.

Kumar V., Ladha JK. 2011. Direct seeding of rice: Recent developments and future research needs. Advances in Agronomy, 111:297-413.

Ladha JK., Dawe D., Pathak H., Padre AT., Yadav RL., Singh B., Singh Y., Singh Y., Singh P., Kundu AL., Sakal R., Ram N. 2003. How extensive are yield declines in long term rice-wheat experiments in Asia? Field Crops Research, 81: 159180.

Ladha JK., Fischer KS., Hossain M., Hobbs PR., Hardy B. 2000. Improving the productivity and sustainability of ricewheat systems of the Indo-Gangetic Plains: A synthesis of NARS-IRRI 
partnership research. Discussion paper no. 40. International Rice Research Institute, Los Baños, Philippines. pp. 1-31.

Rahman MA., Chikushi J., Safizzaman M., Lauren JG. 2005. Rice straw mulching and nitrogen response of no-till wheat following rice in Bangladesh. Field Crops Research, 91:71-81.

Shahin S., Jafari A., Mobli H., Rafiee S., Karimi, M. 2008. Effect of farm size on energy ration for wheat production: a case study from Ardabil province of Iran. AmericanEurasian journal of Agriculture and Environmental Science, 3(4):604-608.

Sidhu HS., Manpreet S., Humphreys E., Yadvinder-Singh, Balwinder-Singh, Dhillon SS., Blackwell J., Bector V., Malkeet S., Sarbjeet S. 2007. The happy seeder enables direct drilling of wheat into rice stubble. Australian Journal of Experimental Agriculture, 47: 844-854.

Singh A., Phogat VK., Dahiya R., Batra SD. 2014. Impact of long-term zero till wheat on soil physical properties and wheat productivity under rice-wheat cropping system. Soil and Tillage Research, 140:98-105.

Sudhir-Yadav, Gill G., Humphreys E., Kukal SS., Walia US. 2011. Effect of water management on dry seeded and puddled transplanted rice. Part 1: Crop performance. Field Crops Research, 120:112-122.

Sys IC., van Ranst E., Debaveye J. 1991. Land evaluation. Part I. Principles in land Evaluation and crop production calculations. International Training Centre for Post-graduate Soil Scientists, University Ghent, Belgium. pp. 265.

Timsina J., Connor DJ. 2001. Productivity and management of rice-wheat cropping systems: issues and challenges. Field Crops Research, 69:93-132.

Tiwari KN. 2002. Balanced fertilization for food security. Fertilizer News, 47:113-122.

Verma TS., Bhagat RM. 1992. Impact of rice straw management practices on yield, nitrogen uptake and soil properties in a wheat-rice rotation in northern India. Fertilizer Research, 33:97-106.

Yadvinder-Singh, Bijoy-Singh, Timsina J. 2005. Crop residue management for nutrient cycling and improved soil productivity in rice-based cropping systems in the tropics. Advances in Agronomy, 85:270-407. 